\title{
CAPITAL \\ FLOWS \\ AND \\ FINANCIAL \\ CRISES
}





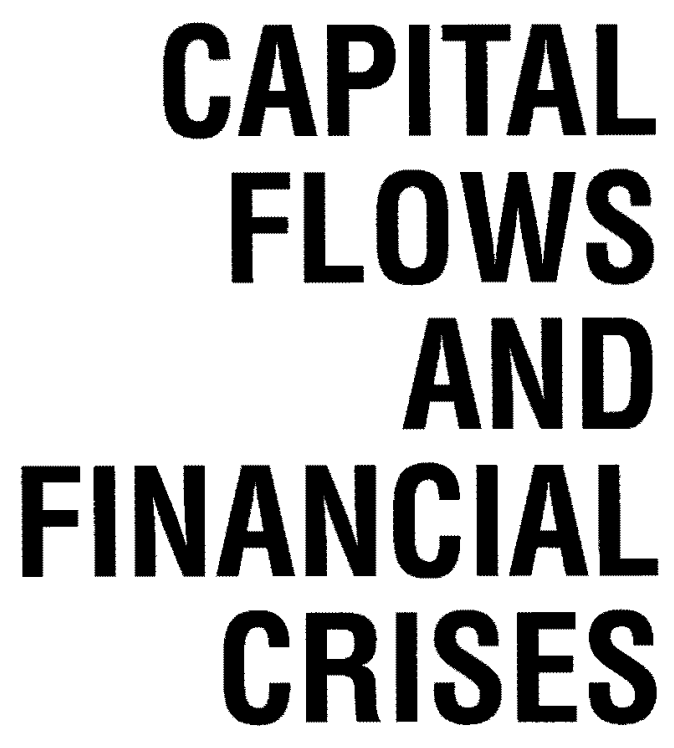

EDITED BY

\section{Miles Kahler}

A COUNCIL ON FOREIGN RELATIONS BOOK

Cornell University Press

ITHACA, NEW YORK 
Copyright $(1998$ by the Council on Foreign Relations, Inc.

The Council on Foreign Relations, Inc., a nonprofit, nonpartisan national membership organization founded in 1921, is dedicated to promoting understanding of international affairs through the free and civil exchange of ideas.

The Council takes no institutional position on policy issues and has no affiliation with the U.S. government. All statements of fact and expressions of opinion contained in all its publications are the sole responsibility of the author or authors.

First published 1998 by Cornell University Press

First printing, Cornell Paperbacks, 1998

Printed in the United States of America

Capital flows and financial crises / Miles Kahler, editor.

p. $\quad \mathrm{cm}$.

Includes index.

ISBN o-8014-3579-X (alk, paper). - ISBN o-8014-8562-2 (pbk.

alk. paper)

1. Capital movements-Developing countries. 2. International

finance. I. Kahler, Miles, 1949-

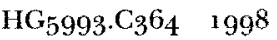

$332^{\prime} .042-\mathrm{dc} 21$

$98-38147$

Cornell University Press strives to use environmentally responsible suppliers and materials to the fullest extent possible in the publishing of its books. Such materials include vegetable-based, low-VOC inks and acid-free papers that are recycled, totally chlorine-free, or partly composed of nonwood fibers.

$\begin{array}{lllllllllll}\text { Cloth printing } \quad 10 & 9 & 8 & 7 & 6 & 5 & 4 & 3 & 2 & 1\end{array}$

Paperback printing $\quad \begin{array}{lllllllllll}10 & 9 & 8 & 7 & 6 & 5 & 4 & 3 & 2 & 1\end{array}$ 